CARAKA: Indonesian Journal of Communications, vol. 2(1), 2021, 20-26

\title{
Pembentukan Persepsi Masyarakat Pekerja terhadap Vaksinasi COVID-19
}

\author{
https://doi.org/10.25008/caraka.v2i1.53 \\ Tansya Calista, Mohammad Shihab \\ President University
}

\begin{abstract}
The Indonesian government decides to carry out a Covid-19 vaccination program to break the chain of COVID-19 spreading in Indonesia. This study aims to explore the perception of workers towards COVID-19 vaccination. This research develops using the qualitative method and phenomenological approach. Seven informants have participated in in-depth interviews and this research concludes that the informants see the COVID-19 vaccination as an antibody to prevent Covid-19. They commit to joining the vaccination after President Jokowi became the first person to get the first dose of the Covid-19 vaccine in Indonesia.
\end{abstract}

Keywords: perception, Covid-19 vaccination, health communication, the perception of workers, chain of COVID-19

\section{ABSTRAK}

Pemerintah Indonesia memutuskan untuk melakukan program vaksinasi Covid-19 untuk memutus mata rantai penyebaran COVID-19 di Indonesia. Penelitian ini bertujuan untuk mengetahui persepsi pekerja terhadap vaksinasi COVID-19. Penelitian ini dikembangkan dengan menggunakan metode kualitatif dan pendekatan fenomenologis. Tujuh informan telah mengikuti wawancara mendalam dan penelitian ini menyimpulkan bahwa para informan melihat vaksinasi COVID-19 sebagai antibodi untuk mencegah Covid-19. Mereka berkomitmen mengikuti vaksinasi setelah Presiden Jokowi menjadi orang pertama yang mendapatkan vaksin Covid-19 dosis pertama di Indonesia.

Kata kunci: Pembentukan persepsi, vaksinasi COVID-19, komunikasi Kesehatan, persepsi pekerja, rantai penyebaran COVID-19

\begin{tabular}{|l|}
\hline Tansya Calista's email: calistatansyaa@gmail.com \\
\hline Para penulis menyatakan tidak mempunyai konflik kepentingan dalam penelitian dan penerbitan publikasi ini. \\
\hline Copyright @ 2021 (Tansya Calista). \\
Licensed under the Creative Commons Attribution-NonCommercial-ShareAlike 4.0 (CC BY-SA \\
4.0) Available at http://caraka.web.id \\
\hline Submitted: 19 April 2021, Revised: 12 May 2021, Accepted: 13 June 2021 \\
\hline
\end{tabular}




\section{PENDAHULUAN}

Severe Acute Respiratory Syndrome Coronavirus 2 (SARS-CoV-2) atau yang lebih dikenal dengan nama COVID-19 merupakan virus yang telah menyebabkan pandemi global sejak kemunculannya pertama kali di Wuhan, Cina pada Desember 2019 (Putri, 2020). Virus ini menyerang sistem pernapasan manusia dengan tingkat gejala yang berbeda-beda, mulai dari gejala ringan hingga infeksi paru-paru yang dapat menyebabkan kematian.

Di Indonesia, kasus COVID-19 terdeteksi pertama kali di bulan Maret 2020. Dua warga yang berdomisili di Depok mengalami gejala yang diyakini sebagai infeksi COVID-19 setelah memiliki riwayat interaksi dengan warga negara Jepang yang tertular COVID-19. Hingga saat ini, pandemi COVID-19 masih berlangsung dengan jumlah kasus lebih dari dua juta jiwa.

Pemerintah pun berupaya untuk memutus rantai penyebaran COVID-19 di Indonesia. Salah satunya dengan mengeluarkan Pembatasan Sosial Berskala Besar (PSBB) yang membatasi pergerakan dan aktivitas masyarakat di luar rumah, dan mematuhi protokol kesehatan yang ditetapkan Pemerintah (Andriani, 2020). Satuan Gugus Tugas (Satgas) Percepatan Penanganan COVID-19 dibentuk dan pandemi COVID-19 ditetapkan sebagai bencana nasional nonalam.

Pembatasan sosial yang disebabkan oleh pandemi COVID-19 berdampak besar pada laju perekonomian nasional. Penyebaran COVID-19 yang luas diyakini telah merugikan negara ratusan triliun rupiah, menyebabkan banyak entitas usaha mengalami kerugian dan gulung tikar, serta mengurangi pendapatan individu (Hadiwardoyo, 2020). Pembatasan sosial harus dilakukan agar dapat mendeteksi, mengisolasi, dan merawat pasien COVID-19 dengan harapan penyebaran dapat ditekan. Hal ini mengingat pada saat itu belum ditemukan obat penyembuh COVID-19, selain menerapkan protokol kesehatan dan vaksinasi.

Pencegahan COVID-19 mendapatkan titik terang setelah pemerintah berhasil mendapatkan vaksin COVID-19 dan memulai proses vaksinasi pada Januari 2021, dimulai dari Presiden Jokowi, tenaga kesehatan, TNI/Polri, aparat sipil negara, tokoh masyarakat, dan warga sipil lanjut usia. Menurut data Satgas COVID-19 per 27 Mei 2021, jumlah penerima vaksin dosis pertama sebanyak 15.703.583 orang dan dosis kedua sebanyak 10.359.996 orang. Pemerintah menargetkan 181.554.465 orang divaksinasi (Rahmawati, 2021).

Usaha pemerintah menekan penyebaran COVID-19 melalui vaksinasi tidak sepenuhnya berjalan mulus. Hasil penelitian (Dewi \& Apriliani, 2021) menyebutkan bahwa masih ada masyarakat yang meragukan dan tidak percaya bahwa COVID-19 itu nyata. Kedatangan jutaan dosis vaksin dan rencana vaksinasi pemerintah mendapatkan berbagai respon. Di media sosial, rencana vaksinasi lebih banyak disambut dengan respon yang positif (Rachman \& Pramana, 2020).

Berangkat dari realitas tersebut, maka penelitian ini dimaksudkan untuk mengeksplorasi persepsi masyarakat terhadap vaksinasi COVID-19. Masyarakat yang menjadi fokus penelitian ini adalah pekerja di Cikarang sebagai salah satu kelompok target program vaksinasi yang diselenggarakan pemerintah (Dewi R. K., 2021). Eksplorasi persepsi masyarakat terhadap vaksinasi ini diharapkan dapat menelusuri bagaimana persepsi terhadap vaksinasi COVID-19 terbentuk.

\section{KERANGKA TEORI}

Kebijakan pemerintah tentang pemberian vaksinasi kepada masyarakat bukan hal yang baru. Dalam penelitian Dethan dan Suariyani (2017) menyebutkan pemerintah Kabupaten Badung pernah mengeluarkan kebijakan vaksinasi Human Papilloma Virus (HPV) massal kepada siswi SMA. Penelitian ini menggambarkan pengetahuan dan sikap perilaku pencegahan kanker serviks melalui vaksinasi HPV terhadap siswi kelas X di SMA. Hasilnya, pengetahuan siswi tergolong rendah dan belum tahu banyak tentang kanker serviks maupun vaksin HPV. 
Penelitian tentang pengetahuan vaksinasi lainnya dilakukan oleh Simbolon, Mulyani, dan Supriyati (2016) yang membahas korelasi pengetahuan, sikap dan persepsi bidan terhadap perilaku pemberian vaksin Hepatitis B di Yogyakarta. Hasil analisisnya menyimpulkan bahwa kebijakan utama untuk mencegah penularan virus hepatitis B adalah dengan memotong jalur penularan sedini mungkin, dan imunisasi menyeluruh pada bayi baru lahir merupakan upaya paling efektif untuk menurunkan prevalensi virus hepatitis B dan karsinoma hepatoselular.

Sebuah masalah kesehatan dapat menimbulkan persepsi yang berbeda-beda. Perbedaan persepsi ini disebabkan oleh faktor fisiologi, umur, budaya, kemampuan kognitif, dan diri sendiri. Persepsi merupakan inti dari proses komunikasi. Persepsi adalah sebuah proses menciptakan makna secara aktif dengan memilih, mengatur, dan menafsirkan orang, objek, peristiwa, situasi, dan fenomena lainnya (Wood, 2016). Pembentukan persepsi terdiri dari tiga proses, yakni menyeleksi, mengatur, dan menginterpretasi.

Proses persepsi dimulai dengan menyeleksi informasi dan menerima stimulasi dari sebuah obyek. Informasi yang diterima ini kemudian diatur ke dalam skema-skema kognitif di dalam otak. Hasil dari pengaturan informasi tersebut akan memudahkan manusia untuk menafsirkan persepsinya dengan cara yang masuk akal (Wood, 2016).

Interpretasi merupakan hasil dari proses selektif yang dilakukan pertama kali ketika menerima informasi. Dalam hal menginterpretasi, dibutuhkan adanya atribusi, yang merupakan penjelasan mengapa sesuatu terjadi atau mengapa seseorang bertindak dengan cara tertentu. Atribusi memengaruhi makna yang kita berikan kepada orang lain dan cara berkomunikasi dengan mereka.

\section{METODOLOGI}

Metode yang digunakan pada penelitian ini adalah metode kualitatif deskriptif dengan pendekatan fenomenologi. Pendekatan fenomenologi digunakan untuk mengetahui esensi pengalaman manusia tentang fenomena langsung dari perspektif informan. Dalam proses ini, peneliti mengesampingkan pengalamannya sendiri untuk memahami informan dalam penelitian (Creswell \& Poth, 2018).

Penelitian ini dilakukan di sebuah perusahaan di Kawasan Industri MM 2100, Cikarang, Jawa Barat. Perusahaan ini memiliki 18 karyawan dengan berbagai latar belakang usia, jenis kelamin, dan tempat tinggal. Dari keseluruhan jumlah tersebut, Peneliti mewawancara tujuh pekerja dengan rentang usia 22-60 tahun, tiga laki-laki, dan empat perempuan, untuk menggali bagaimana pandangan, serta mengidentifikasi apa yang membentuk persepsi mereka tentang vaksinasi COVID-19.

Wawancara semi-terstruktur dilakukan agar data yang diperoleh relevan dengan topik yang sedang diteliti dan dapat membuat peneliti memperkaya informasi dengan mengajukan pertanyaan susulan.

Peneliti juga menggali data sekunder yang relevan dengan topik penelitian ini dari sumber sekunder seperti laporan penelitian, jurnal, dan media online nasional bereputasi.

\section{HASIL PENELITIAN}

Informasi terkait COVID-19 diterima masyarakat dari berbagai media tradisional, media online, dan media sosial. Hasil wawancara dengan informan menyimpulkan, mereka mengakses lebih banyak informasi melalui media digital dan media sosial daripada koran, radio, dan televisi. Hal ini karena media digital dan media sosial dianggap lebih mudah diakses melalui smartphone.

“....nonton TV masih sih ...cuma malam-malam tuh kalau pas lagi nyalain TV dan ada berita ya aku tonton. Cuma ya jarang kalau nyalain TV ya, lebih ke Detik.com karena itu kan di handphone, HP itu kan kita bisa bawa sambil Pembentukan Persepsi Masyarakat Pekerja terhadap Vaksinasi COVID-19 (Tansya Calista, Mohammad Shihab 
ngapain gitu kan... Medsos Facebook, eh Instagram...paling Lambe Turah doang nih" (S, 30 tahun).

Menariknya, seorang informan mengaku mencari informasi yang sedang ramai diperbincangkan melalui twitter dan para influencer di twitter.

"Ya kalau untuk medsos itu yang paling sering digunakan sih Twitter karena pengen tahu apa yang trending hari ini... Biasanya ngikutin berita dari influencer... Paling influencer kayak artis gitu aku follow karena suka..." (N, 22 tahun).

Sebelum memutuskan untuk mengambil solusi kesehatan, masyarakat harus lebih dulu memahami apa itu vaksin. Hasil wawancara menemukan, enam informan mengetahui apa itu vaksin dan bagaimana vaksin bekerja. Keenam informan paham bahwa vaksin berisi virus yang sudah dilemahkan dan disuntikkan untuk membentuk antibodi di dalam tubuh penerima vaksin.

Menariknya, salah satu informan mengaku memahami cara kerja vaksin dari buku bacaan anak-anak.

"Vaksin itu kan antibody yang disuntikan kedalam tubuh manusia. Eem gini kebetulan aku sudah punya anak...ada bukunya. Dan itu fungsinya vaksin untuk apa itu ada sih...aku lebih ke arah mengikuti rekomendasi dokter." (Ch, 33 tahun).

Vaksinasi COVID-19 sudah mulai dilaksanakan di Indonesia pada 13 Januari 2021. Orang pertama yang melakukan vaksinasi adalah Presiden Joko Widodo dan sejumlah tokoh masyarakat, tenaga kesehatan, dan pemuka agama. Kegiatan vaksinasi yang disiarkan secara langsung ini pun membuat para informan percaya dengan vaksin COVID-19.

"Iya. sebelumnya, sebelum dipromosikan, belum diuji coba sama Presiden saya nggak percaya, apalagi notabene itu asal Cina... Karena sudah diuji klinis ya mbak, bukan asal terima dari Cina, uji klinis BPOM selesai, itu. Pada dasarnya memang saya tidak percaya, tapi setelah dipromosikan oleh Kepala Negara baru saya percaya, bahwa itu vaksinnya COVID-19... Saya percaya karena promosi pertama itu Kepala Negara, sudah banggalah, berani dia vaksin." (L, 33 tahun).

Sementara itu, informan lainnya menyatakan kesediaannya untuk divaksin karena percaya dengan tindakan Pemerintah. Menurutnya, Pemerintah tidak akan berani menggunakan vaksin yang tidak kredibel karena hal itu dapat menyebabkan kasus yang sangat besar.

"Kalau ada vaksin COVID-19 di depan aku dan dikasih sama Pemerintah ya percaya ya, inikan Pemerintah, masa Pemerintah kita sendiri kita ga percaya sih, terus siapa lagi yang harus kita percaya kalau begitu...Pemerintah punya tanggung jawab, jadi kalau misalnya tiba-tiba rakyatnya mati semua itu kan bakalan dilihat oleh dunia gituloh, seperti WHO atau apalah gitu. Jadi kalau misalnya seperti malpraktik itu bakalan jadi kasus yang sangat besar ya" (L, 33 tahun).

Dari hasil wawancara, enam informan setuju untuk mengikuti vaksinasi COVID-19. Keenam informan ini bersedia mengikuti vaksinasi COVID-19 karena percaya dengan program Pemerintah. Salah seorang informan mengaku ingin menjadi relawan vaksinasi COVID-19, tetapi gagal karena tidak berdomisili di Bandung.

"Saya malah minta (tapi) gak boleh, belum boleh. Saya waktu itu daftar gak boleh, domisilinya harus di Bandung waktu jadi relawan saya sempat daftar" (I, 48 tahun). 
Dari kelompok perempuan yang menjadi informan, mereka bersedia mengikuti vaksinasi selama gratis atau disubsidi. Mereka enggan mengikuti vaksinasi COVID-19 bila harus berbayar.

"Saya lebih bagus gratis tapi nunggu lama, ikut program Pemerintah saya ikut... Kalau berbayar...subsidi mau, bayar full no... Kalau kondisinya lagi slow seperti ini lalu aku disuruh bayar, ya sorry aja aku no ya. Better nunggu, better menjaga diri sendiri pakai vitamin, pakai apa segala gitu sih..." (I, 48 tahun).

Sementara itu, satu informan mengaku belum bersedia divaksinasi karena kendala kesehatan. la menerima informasi dari dokter bahwa vaksin COVID-19 belum layak untuk penderita autoimun seperti dirinya.

"Bukannya ga mau divaksin, kita menunggu sampai penelitiannya lebih lanjut saja. Ditunda, bukannya tidak divaksin...untuk saat ini belum...kebetulan aku autoimun...dokter-dokter di sana pokoknya sudah riset setelah melihat vaksin tersebut menyimpulkan bahwa vaksin ini tuh belum layak (untuk penderita autoimun) dan menurut penelitiannya tersebut juga tidak dijelaskan bahwa dalam laporan penelitian itu tidak dilakukan untuk orang yang punya kasus autoimun..." (L, 33 tahun).

Proses seleksi informasi tentang vaksinasi COVID-19 adalah tahap awal dalam pembentukan persepsi. Dalam penelitian ini ditemukan bahwa kelompok pria lebih tertarik terhadap fenomena vaksinasi sehingga mereka mencari informasi lebih banyak sejak awal berita vaksinasi disiarkan di media tradisional, seperti Metro TV, koran Kompas, radio Elshinta, hingga media digital seperti Detik.com. Sementara itu, kelompok informan perempuan hanya kebetulan saja melihat informasi tersebut, misalnya secara tidak sengaja muncul saat membuka media sosial atau di laman portal berita daring karena influencer mengunggah informasi mengenai Vaksin COVID-19 dalam bentuk infografik di Instagram, Twitter, dan Youtube. Ada juga yang membaca artikel terkait rencana Vaksin COVID-19 berbayar khusus untuk pelaku usaha, didapat dari portal berita.

Secara umum pengertian vaksinasi sudah diketahui oleh para informan, mereka juga menjelaskan bahwa vaksin bukan obat dan hanya digunakan untuk membentuk antibodi dalam diri. Satu dari tujuh informan pernah melakukan vaksinasi secara mandiri pada usia dewasa, yaitu vaksin campak, sisanya beranggapan mereka belum membutuhkan vaksinasi mandiri di luar program pemerintah. Mereka melakukan pola hidup sehat, namun ada pula informan yang mengaku kurangnya informasi dan edukasi tentang vaksin.

Informasi tentang vaksinasi COVID-19 memang menuai banyak pro dan kontra. Tidak sedikit masyarakat menolak vaksinasi karena banyaknya informasi yang beredar. Penolakan masyarakat terhadap vaksin merupakan salah satu hasil pembentukan persepsi tentang vaksinasi COVID-19. Informasi awal yang diterima merupakan bentuk penolakan terhadap fenomena tersebut, lalu mereka memilih mengonsumsi berita sesuai dengan ketertarikannya, sehingga dapat menyimpulkan dirinya menolak vaksinasi.

Berita hoaks lain terkait vaksinasi COVID-19 dikatakan Informan S dalam wawancara dengan peneliti. Dia mendapat berita hoaks bahwa vaksin COVID-19 dimasukan oleh Bill Gates karena yayasannya menjadi penyumbang terbesar pembuatan vaksin ini. Hal ini dikonfirmasi melalui laman berita daring Tempo yang menyebutkan bahwa berita tersebut adalah tidak benar.

Berbagai peraturan dikeluarkan Pemerintah untuk mencegah perkembangan COVID-19 mulai dari PSBB hingga vaksinasi COVID-19 wajib bagi seluruh rakyat Indonesia. Pemerintah mengeluarkan strategi komunikasi agar masyarakat mau melakukan vaksin COVID-19 dengan menerbitkan Peraturan Pemerintah No. 84 Tahun 2020 tentang Pelaksanaan Vaksinasi Dalam Rangka Penanggulangan COVID-19. Strategi komunikasi dilakukan Pemerintah Pusat dan Daerah untuk meningkatkan pemahaman, sikap masyarakat agar termotivasi untuk melakukan vaksinasi 


\section{COVID-19.}

Pada 13 Januari 2021 Presiden Joko Widodo menjadi orang pertama yang menerima vaksinasi COVID-19, kemudian disusul oleh sejumlah pejabat, tokoh agama, organisasi profesi, dan perwakilan masyarakat. Sempat beredar berita hoaks bahwa vaksinasi yang dilakukan Presiden adalah Vitamin C dan Vitamin B, namun laman daring covid.go.id menyatakan berita itu adalah hoaks. Vaksin yang diterima Presiden Jokowi adalah vaksin Sinovac.

Vaksinasi terhadap Presiden Jokowi menjadi salah satu stimulus bagi kelompok masyarakat agar mereka termotivasi dan percaya bahwa Program Vaksinasi yang diadakan Pemerintah adalah benar-benar Vaksin COVID-19 sebagai upaya pencegahan penyebaran virus tersebut. Publikasi vaksinasi COVID-19 oleh Presiden Jokowi mampu mengubah persepsi yang terbentuk dalam kelompok masyarakat. Untuk itu perlu diadakan lebih banyak publikasi vaksinasi dan informasi edukasi oleh tokoh masyarakat agar masyarakat tergerak untuk melakukan vaksinasi.

Sampai dengan penelitian ini dilakukan sudah lebih dari dua ribu perusahaan mendaftarkan diri ikut program Vaksinasi Gotong-Royong untuk para karyawannya melalui Kamar Dagang Industri, namun belum ada peraturan resmi dari Menteri Kesehatan mengenai harga vaksin untuk Vaksinasi Gotong Royong.

Vaksinasi COVID-19 menggunakan Sinovac dari China, dan berdasarkan Peraturan Menteri Kesehatan No. 10 Tahun 2021 tentang Pelaksanaan Vaksinasi Dalam Rangka Penanggulangan COVID-19, tertulis pendanaan vaksinasi ditanggung atau dibebankan kepada Pemerintah melalui Anggaran Pendapatan dan Belanja Negara maupun Daerah. Pemerintah juga memberikan program vaksinasi bagi pihak swasta yang ingin melaksanakan vaksin lebih dulu melalui Vaksinasi Gotong Royong yang pendanaannya ditanggung atau dibebankan kepada Badan Hukum atau Badan Usaha.

\section{KESIMPULAN}

Persepsi yang terbentuk pada kelompok masyarakat di perusahaan yang menjadi obyek penelitian ini memandang Vaksin COVID-19 sebagai antibodi untuk menangkal virus corona masuk ke dalam tubuh manusia, dan sebagai fenomena baru yang menjadi atensi kelompok masyarakat tersebut, sehingga mereka mencari informasi mengenai vaksin COVID-19 dan menginterpretasikannya untuk mengedukasi sesama, minimal orang terdekatnya.

Tidak semua masyarakat pernah melakukan vaksinasi. Dalam penelitian ini para informan bersedia melakukan vaksinasi COVID-19 meskipun ada yang menunda karena alasan Kesehatan. Mereka termotivasi karena Presiden Joko Widodo menjadi orang pertama yang divaksinasi sehingga diyakini jika vaksinasi yang dilakukan adalah upaya pencegahan Pemerintah adalah solusi paling baik untuk memerangi COVID-19 di Indonesia.

Vaksinasi COVID-19 menjadi solusi yang ditawarkan oleh Pemerintah dan sampai saat ini masih terus dilakukan penelitian ataupun uji klinis agar Vaksin COVID-19 aman dikonsumsi untuk semua kalangan masyarakat.

\section{DAFTAR PUSTAKA}

Andriani, H. (2020). Effectiveness of Large-Scale Social Restrictions (PSBB) toward the New Normal Era during COVID-19 Outbreak: a Mini Policy Review. Journal of Indonesian Health Policy and Administration, 5(2), 61-65. doi:10.7454/ihpa.v5i2.4001

Creswell, J. W., \& Poth, C. N. (2018). Qualitative Inquiry and Research Design: Choosing among Five Approaches. Los Angeles: Sage Publications.

Dewi, R. K. (2021, April 23). Vaksinasi Gotong Royong bagi Pekerja Swasta Dimulai Mei 2021. Diambil kembali dari Kompas.com: 
https://www.kompas.com/tren/read/2021/04/23/181500465/vaksinasi-gotong-royong-bagipekerja-swasta-dimulai-mei-2021?page=all

Dewi, R., \& Apriliani, I. (2021). Studi Fenomenologi Persepsi Masyarakat Dalam Penerapan Protokol Covid-19. REAL in Nursing Journal (RNJ), 4(1), 44-49. Retrieved from https://ojs.fdk.ac.id/index.php/Nursing/article/view/1199

Hadiwardoyo, W. (2020). Kerugian Ekonomi Nasional Akibat Pandemi COVID-19. Baskara: Journal of Business and Entrepreneurship, 2(2), 83-92. doi:https://doi.org/10.24853/baskara.2.2.83-92

Putri, R. N. (2020). Indonesia dalam Menghadapi Pandemi Covid-19. Jurnal IImiah Universitas Batanghari Jambi, 20(2), 705-709. doi:10.33087/jiubj.v20i2.1010

Rachman, F. F., \& Pramana, S. (2020). Analisis Sentimen Pro dan Kontra Masyarakat Indonesia tentang Vaksin COVID-19 pada Media Sosial Twitter. Indonesian of Health Information Management Journal, 8(2), 100-109. Diambil kembali dari https://inohim.esaunggul.ac.id/index.php/INO/article/view/223

Rahmawati, W. T. (2021, Mei 28). Vaksinasi Covid-19 Indonesia dosis kedua mencapai 10,36 juta hingga Kamis (27/5). Diambil kembali dari Kontan.co.id: https://kesehatan.kontan.co.id/news/vaksinasi-covid-19-indonesia-dosis-kedua-mencapai1036-juta-hingga-kamis-275

Simbolon, L. N., Mulyani, N. S., \& Supriyati, S. (2016). Korelasi Pengetahuan, Sikap dan Persepsi Bidan Terhadap Perilaku Pemberian Vaksin Hepatitis B Saat Lahir. Sari Pediatri, 18(2), 106-110. Diambil kembali dari https://www.saripediatri.org/index.php/saripediatri/article/download/7/380

Wood, J. T. (2016). Communication Mosaics: An Introduction to The Field of Communication. Canada: Cengage Learning. 